\section{The Department of Horticulture and Landscape Architecture at the University of Kentucky}

Horticulture has a long history at the Univ. of Kentucky (UK). In the late 1800s, our college was the College of Horticulture and Agriculture. The history of UK horticulture is highlighted by many achievements. Emery Emmert is considered the "father of the plastic greenhouse and rowcovers" as a result of his research during the 1950s. Other innovations by horticulture faculty encompassed the development and release of several cultivars of iris and strawberry and greenhouse environmental control systems.

Today, the department represents two disciplines, horticulture and landscape architecture, and consists of 24 faculty members, two research specialists, and 19 staff members conducting statewide extension, research, and teaching programs. Ten faculty members have primary responsibility in extension; eight have primary research responsibilities; and five have primary responsibility in undergraduate teaching.

The department offers BS and MS degrees in plant and soil science with an emphasis in horticulture and an accredited BS degree in landscape architecture. The department cooperates with agronomy, forestry, and plant pathology faculty to offer $\mathrm{PhD}$ degrees in crop science and plant physiology/biochemistry/ molecular biology.

The mission of the university's horticulture program is to expand knowledge, develop and evaluate new technologies for appropriate use of environmental resources, and deliver information to relevant horticultural clienteles for improving the quality of life in Kentucky, the United States, and the world. This mission is accomplished through undergraduate education, research, graduate studies, and extension programs. The horticulture faculty is committed to interdisciplinary research and education. Faculty with complementary expertise from several departments form planning and action teams, such as integrated pest management programs, production and marketing systems for vegetables, and models for crop management in controlled environments.

Received for publication 19 Dec. 1995. Accepted for publication $19 \mathrm{Dec}$. 1995. The cost of publishing this paper was defrayed in part by the payment of page charges. Under postal regulations, this paper therefore must be hereby marked advertisement solely to indicate this fact.

${ }^{1}$ Department Chair and Professor.

Front cover: The Juddmonte Horse Farm, Lextington, Ky., designed by Prof. Horst Schach (horse-farm design specialist, Univ. of Kentucky Landscape Architecture Program) in the late 1980s.
Two areas of emphasis, horticultural enterprise management and horticultural science, are offered in a BS curriculum in plant and soil science. The horticultural enterprise management emphasis combines horticultural knowledge with business and economics expertise to prepare students for entry into the horticultural industries. The horticultural science program stresses the basic sciences of chemistry, biochemistry, and plant physiology.

Although classroom and laboratory instruction provides the backbone of our undergraduate curriculum, the array of extracurricular activities that expose students to public horticulture and horticultural industries throughout

\section{INSTRUCTION}

the United States and western Europe distinguishes our program. For example, within the past 2 years, faculty have coordinated student trips to western Europe, Oregon, New England, California, and Quebec and Ontario, Canada, as well as in Kentucky and surrounding states. Student teams prepare annually to compete in the Associated Landscape Contractors of America Field Day and the Floral Crop Quality Evaluation Competition. Many students also take advantage of opportunities to travel with professors to industry and professional meetings, such as the ASHS Southern Region, the Southern Nurserymen Association's Research Conference and Trade Show, the Garden Centers of America/Nursery and Landscape Association Management Clinic, the International Floriculture Short Course, and regional meetings of the International Plant Propagators' Society. The Horticulture Club is active on campus through service projects, fund-raising efforts, and social/ educational events.

Instruction in landscape architecture is provided through a nationally accredited, 5-year, undergraduate program supported by five land-

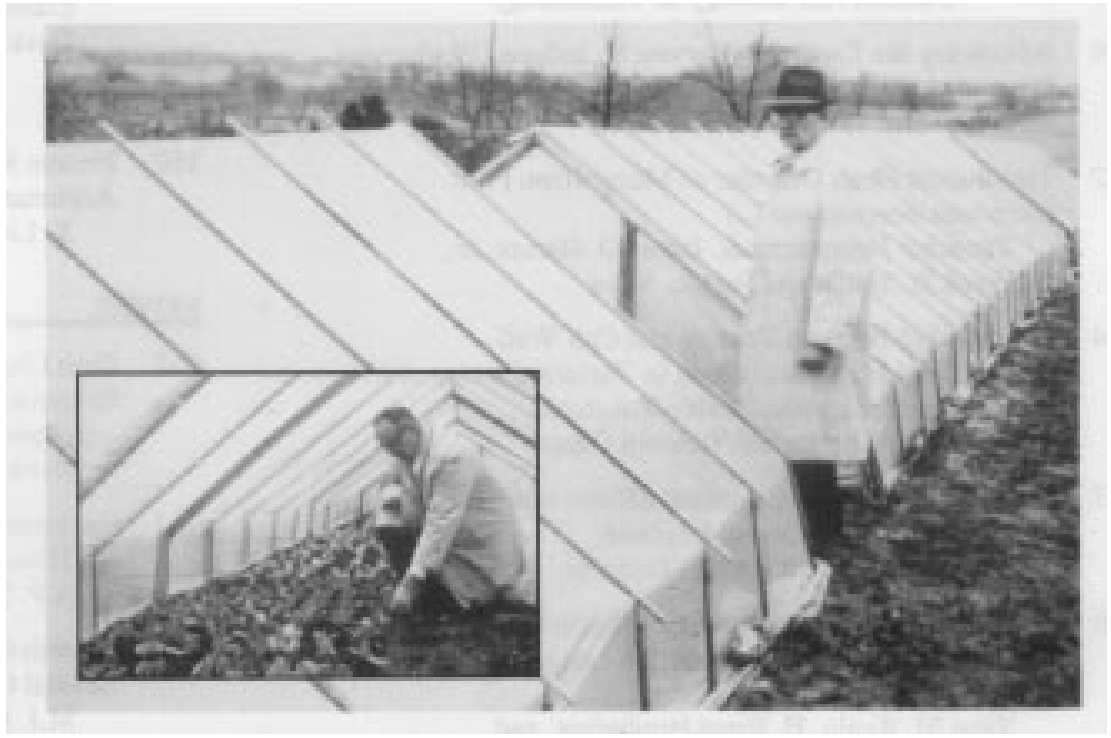

Emery Emmert, father of plastic-covered greenhouses and rowcovers.

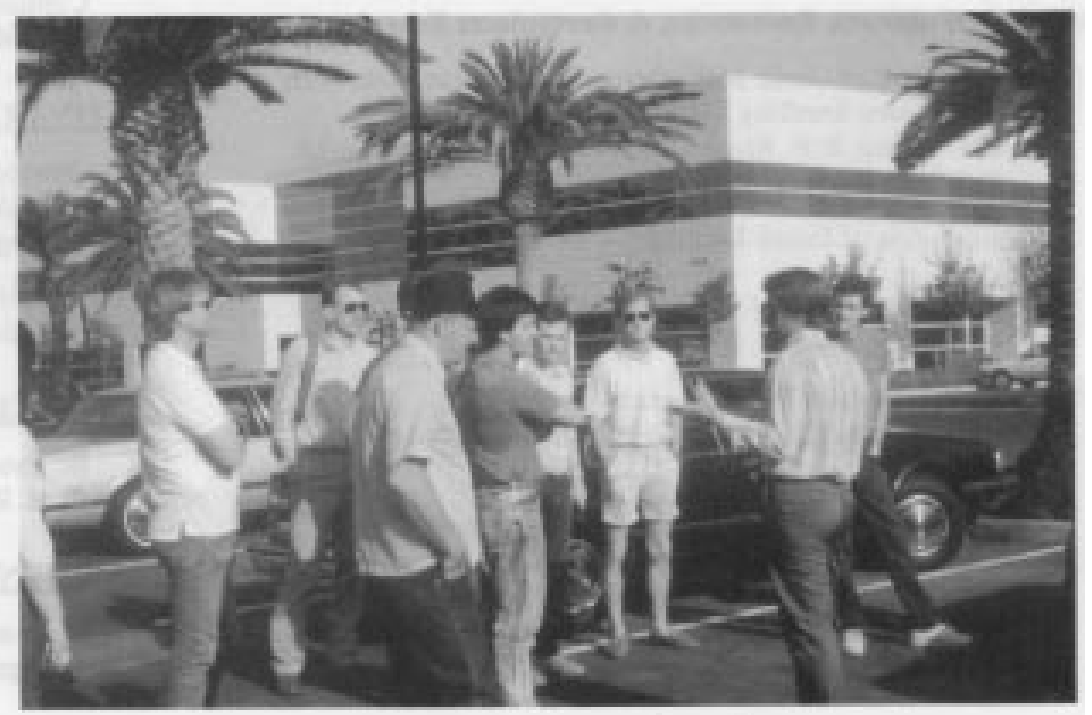

United States and European industry tours enhance classroom instruction. 


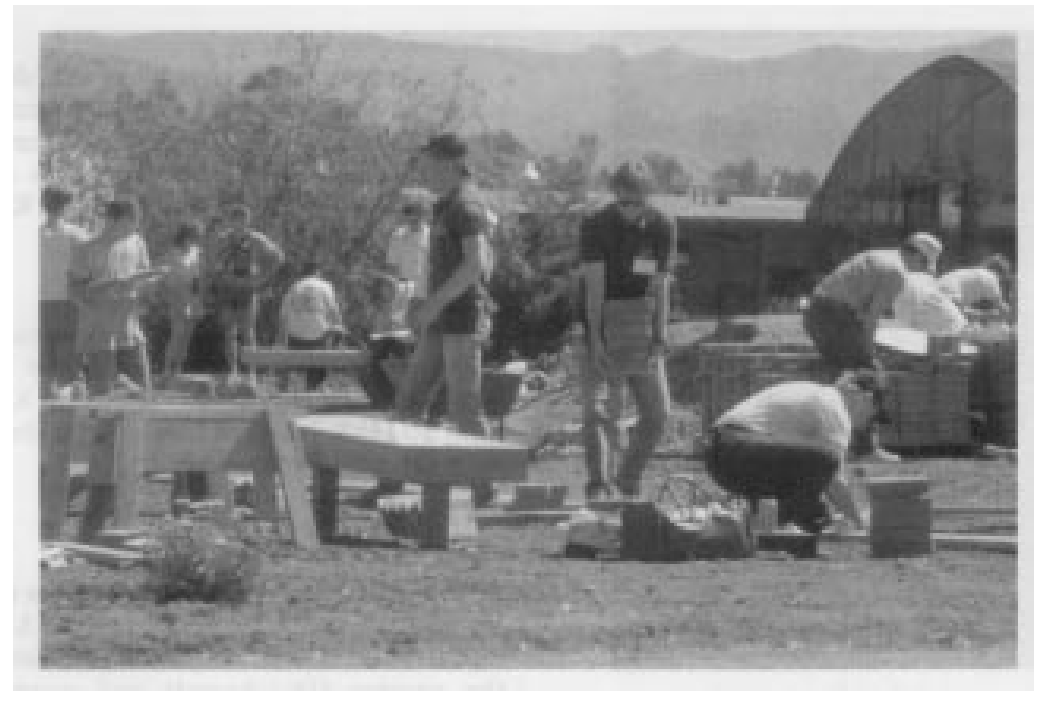

Students compete annually in the Associated Landscape Contractors of America Field Day.

scape architecture faculty members and a research specialist. A selective admissions program limits annual admissions to 25 . Six to eight practicing landscape architects are hired part-time each year as adjunct instructors. These practitioners assist in the studios to enrich the classroom experience.

\section{RESEARCH}

Basic and applied research addresses current and anticipated needs and opportunities related to the production and use of horticultural crops. This is accomplished through individual effort and contributions to interdisciplinary teams of research and extension faculty focusing on broad and/or complex issues. Research areas include plant/pest interface chemistry; carbon assimilation; photosynthesis; growth and development; weed biology and management; plant tissue culture; crop production systems for fruits, floriculture, vegetables, and landscape plants; controlled plant production environments; volatile natural plant products; molecular biology; and a geographic information system for surfacemined land. Extramural support for research in 1995 included two U.S. Dept. of Agriculture National Research Initiative grants, a U.S. Dept. of Energy grant, and many smaller industry grants and gifts totaling more than $\$ 400,000$.

Efforts are focused on the following disciplinary areas:

\section{Integrated crop management}

-Nitrogen application techniques to improve $\mathrm{N}$ recovery and use through studies of $\mathrm{N}$ metabolism and allocation patterns in small fruits.

-Water requirements for crop plants as related to plant stress, crop productivity, and irrigation technology.

-Weed biology and their management with natural products (sorgoleone and others), horticultural practices, and chemical control.

-Seed dormancy mechanisms and germination.

\section{Crop improvement} it relates to $\mathrm{CO}_{2}$ fixation. drought stress resistance. provement of tomato. postharvest environments. selected management systems. woody perennial plants. lism and development.
-Evaluation and introduction of plant materials that offer commercial potential and development of appropriate, efficient systems to produce these plants and yield alternative products.

-Evaluation of new plant varieties that are commercially available or have significant potential of being released under Kentucky conditions.

-New molecular targets and biochemical pathways for improvements in crop productivity.

Environmental sciences and regulation of plant growth and development

-Response to environmental stress and adaptive mechanisms in perennial horticultural crops.

-Regulation of carbohydrate assimilation and metabolism in controlled environments to optimize plant quality.

-Development of a basic Geographic Information System (physical, economic, and social cultural factors) of surface-mined land provides data for regional land-use planning.

-Rubisco structure and modification as

-Analysis of strawberry germplasm for

- Chemical and physical interactions at the plant/pest interface to advance cultivar selection and the genetic im-

- Naturally occurring volatile compounds and their effect on organisms pathogenic to plants and/or people in

- Fruit tree rootstock performance in

-In vitro culture and transformation of

-Application of image analysis technologies in root development research to optimize container production systems.

-Apple fruit carbohydrate metabo-

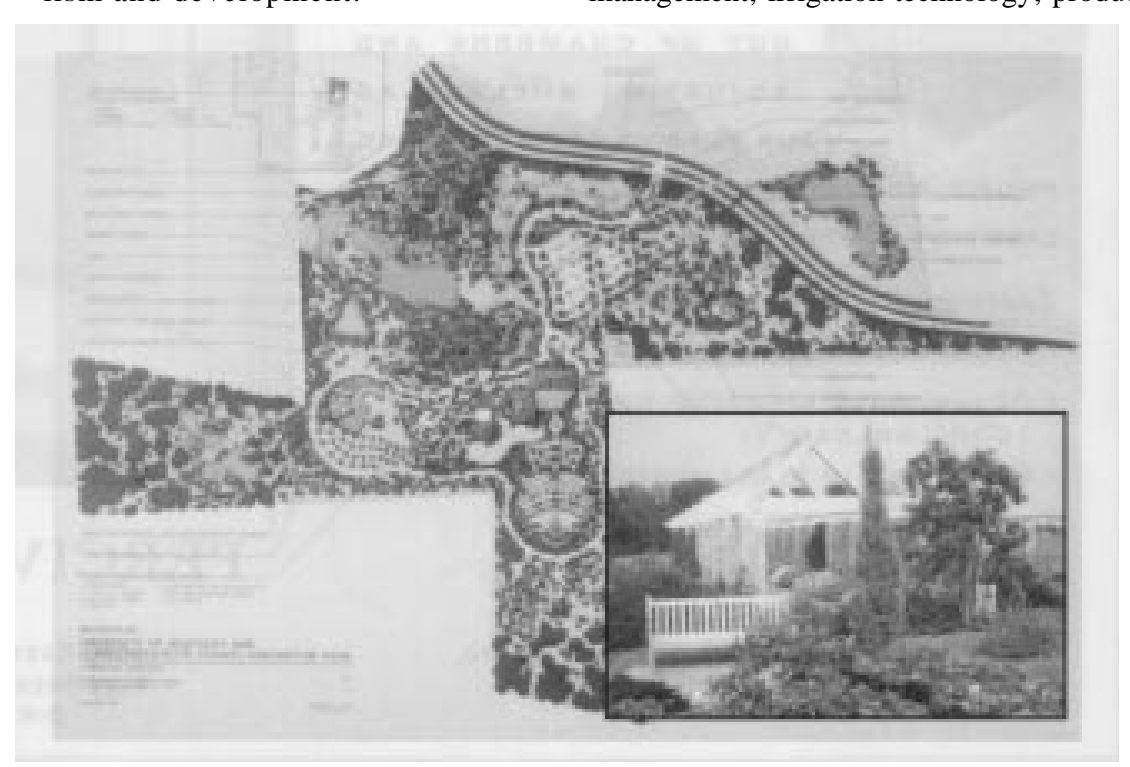

Development of a 40-ha arboretum on campus continues.

\section{EXTENSION}

Each faculty member with a primary extension appointment has a commodity assignment and takes responsibilities in one or more program areas across commodities. Assignments include nursery crops/landscape horticulture, floriculture, fruits and nuts, vegetables, consumer horticulture, and horticultural youth programs. Efforts are coordinated to study and demonstrate sustainable production/marketing systems. Cross-commodity areas of expertise include direct marketing, educational delivery methods, water resource management, waste management and use, integrated pest management, and food safety. Extension faculty in other departments add expertise to the team in the identification, biology, and control of diseases and insects; soil science; turfgrass management; irrigation technology; produc- 


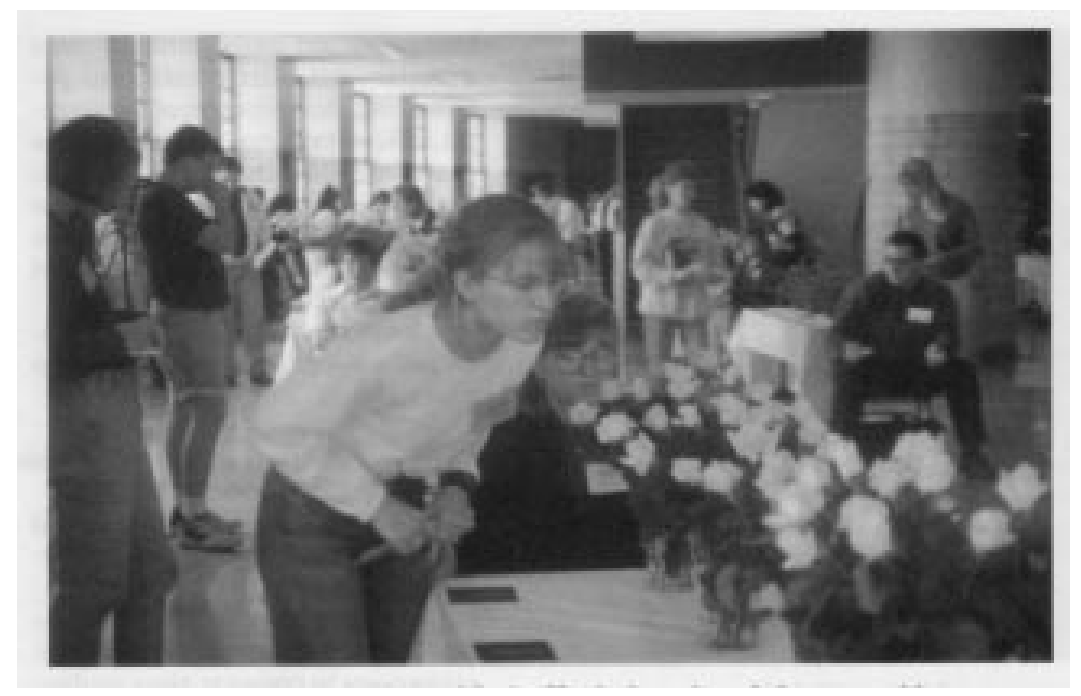

High school students participate in National Junior Horticulture Association competitions.

tion economics; marketing; environmental control; and mechanization.

Horticulture extension program are focused in the following primary areas:

\section{Integrated crop management/marketing}

A "systems" approach is used to intensify horticultural crop production and marketing using integrated pest management practices, biological and chemical pest control, cultivar evaluation, low/no-tillage soil management, multiple-cropping strategies with tobacco and vegetables, crop rotation (nitrogen use), waste recycling technologies, food safety awareness, and packing and storage strategies.

\section{Landscape horticulture} environment.

\section{Consumer horticulture}

Teaching consumers fundamental skills necessary for identifying and using quality products and services will enhance the market for horticultural products and services and improve the health and well-being of Kentucky citizens.

\section{Horticultural training for youth}

Resource materials and statewide leadership provide educational opportunities for Kentucky's youth and participation in Kentucky and U.S. National Junior Horticultural Association activities.

\section{FACILITIES}

Horticultural research is conducted at two agricultural experiment station farms in Lexington and at research and education centers in the eastern (Quicksand) and western (Princeton) regions of the state. Research and teaching greenhouses and growth chambers are located on campus and at the Horticultural Research Farm in southern Lexington.

For more information, contact the Dept. of Horticulture and Landscape Architecture, N-324 Agricultural Science-North, Univ. of Kentucky, Lexington, KY 40546-0091; phone 606.257.1601 or via the World Wide Web (http://www.uky.edu/Agriculture/HLA/).

Education of arborists, landscape contractors, landscape managers, garden center personnel, and consumers focuses on the proper selection, handling, establishment, and maintenance of all landscape plants in the urban
Dewayne L. INGRAm ${ }^{1}$

Dept. of Horticulture and Landscape Architecture

Univ. of Kentucky

Lexington, KY 40546-0091 